\title{
A zoogeographic study of the limnoterrestrial tardigrade fauna on the Faroe islands
}

\author{
Birna VÁR TRYGVADÓTTIR, ${ }^{1 *}$ Reinhardt MØBJERG KRISTENSEN²
}

${ }^{1}$ Kaldbak Marine Biological Laboratory, Mjólkargøta 7, FO-180 Kaldbak, Faroe islands; ${ }^{2}$ The Natural History Museum of Denmark, Zoological Museum, Invertebrate Department, University of Copenhagen, Universitetsparken 15, DK-2100 Copenhagen Ø, Denmark *Corresponding author: birnat@savn.fo

\begin{abstract}
The Faroe islands $\left(62^{\circ} \mathrm{N}, 7^{\circ} \mathrm{W}\right)$ are an archipelago of 18 small islands situated in the northeast Atlantic ocean between Iceland and the Shetland islands. A zoogeographic investigation (2001-2004) of the limnoterrestrial tardigrade fauna of these islands revealed 48 limnoterrestrial species and subspecies and one marine species, of which 29 were new records for the Faroe islands. Among the findings were three species in the recently described genus belonging to the family Eohypsibiidae. A faunistic comparison was also done with Iceland, Svalbard islands, Disko island (Greenland), Greenland (West and East), Scotland, England and with Newfoundland. On the basis of presencelabsence data of the tardigrade species from the different countries a cluster analysis was computed, based on BrayCurtis similarities, and a dendrogram was constructed. The interesting results show that the Faroese tardigrade fauna is mostly similar with Iceland, which could be expected, but more surprising it is also very similar to the tardigrade fauna on Disko island (West Greenland). Several of the reported species exhibit a boreo-alpine disjunction (i.e. species only found in northern latitudes and in high altitudes farther south). These facts could indicate that the tardigrade fauna on the islands is very ancient and could have survived glaciation periods in refuges such as nunataks which occurred on the Faroes during glaciation periods. This study also includes a closer inspection of the altitudinal distribution of the tardigrade species found compared with similar data from Poland.
\end{abstract}

Key words: limnoterrestrial tardigrades, Austeruseus, Eohypsibiidae, zoogeography, altitudinal distribution, Faroe islands, similarity.

\section{INTRODUCTION}

The Faroe islands $\left(62^{\circ} \mathrm{N}, 7^{\circ} \mathrm{W}\right)$ are an archipelago of 18 small islands situated in the northeast Atlantic ocean between Iceland and the Shetland islands. Tardigrade records from these islands are scarce and published in only a few papers. The first record was published over a century ago by Sellnick (1908), who reported 13 species from mosssamples from the three islands Borðoy, Streymoy and Suðuroy (Fig. 1). He included some specimens identified as Echiniscus sp. and gave an illustration of one specimen. Having only this drawing and a limited description, it is impossible to state with certainty the species, but it appears to be similar to either Echiniscus merokensis suecicus Thulin, 1911 or Echiniscus quadrispinosus cribrosus Murray, 1907, the two of which are easily mistaken. Twenty years later, Thulin (1928) published his monograph Über die Phylogenie und das System der Tardigraden in which he described a new species, i.e. Diphascon tenue Thulin, 1928, found on the island Suðuroy, $250 \mathrm{~m}$ asl. In this work he also erected a new genus, Hypechiniscus, into which he transferred Echiniscus gladiator Murray, 1905, and its variety Echiniscus exarmatus Murray, 1907, now a valid species (Guidetti and Bertolani, 2005). Thulin (1928) mentioned that the form exarmatus examined by him was from the Faroe islands, thus adding even one more to the species list. Tuxen
(1941) added four species to the fauna, of which only one species is valid today, i.e. Dactylobiotus ambiguus (Murray, 1907). Two are stated as species inquirendae, i.e. Macrobiotus dubius Murray, 1907 and Dactylobiotus macronyx (Dujardin, 1851) (Guidetti and Bertolani, 2005). Furthermore we are not even sure that Tuxen's species is a Dactylobiotus. In addition one specimen was designated as Isohypsibius sp., not described in detail, and therefore impossible to identify. One of the more recent records was one individual of Eohypsibius nadjae Kristensen, 1982 found in a homothermic spring $\left(12^{\circ} \mathrm{C}\right)$ at $V i ð$ Áir on Streymoy reported by Bertolani and Kristensen (1987). This individual was found in a soil sample taken from the spring. This was the first time E. nadjae was found south of the Arctic circle, in addition to findings from the Alps and Apennines (Bertolani and Kristensen, 1987; Manicardi and Bertolani, 1987; Bertolani et al., 1996), since its discovery in homothermic springs on Disko island, Greenland, in 1978-1979 (Kristensen, 1982). In 2006, Pilato et al. erected a new genus, Borealibius, into which they transferred Hypsibius zetlandicus (Murray, 1907). Some of the specimens they examined were from the Faroes, collected by B.V. Trygvadóttir, and also included in the present work. The latest addition to the Faroese fauna was published in Trygvadóttir and Kristensen (2011), in which Bertolanius weglarskae (Dastych, 1972) and a rediscovery of E. nadjae were reported and a 
new genus, Austeruseus, was described. Members of this genus were found primarily in moss samples at high mountain biotopes and included three species: Austeruseus faeroensis Trygvadóttir and Kristensen, 2011, Austeruseus balduri Trygvadóttir and Kristensen, 2011 and Austeruseus rokuri Trygvadóttir and Kristensen, 2011.

The central position of the Faroe islands in the middle of the northeast Atlantic ocean makes a comparison between the tardigrade faunas on the surrounding islands and countries very interesting from a zoogeographical point of view. Given that tardigrade eggs are dispersed by winds as well as by other means (Ramazzotti and Maucci, 1983; Kinchin, 1994), the Faroe islands could act as a stepping stone in the dispersal of tardigrade species.

\section{METHODS}

Samples were collected on four of the largest islands, Eysturoy, Streymoy, Vágoy and Suðuroy, from the Faroe island archipelago $\left(62^{\circ} \mathrm{N}, 7^{\circ} \mathrm{W}\right)$ over the years 2001-2004 as part of the first author's (B.V. Trygvadóttir) master's project (Fig. 1). The study also included specimens from the second author's (R.M. Kristensen) personal collection from the Faroe islands dated from 1979-1992. The main part of the material consisted of different types of moss cushions sampled from large rocks and bedrock. In addition, moss growing on vertical rocksides with seeping freshwater, moss/vegetation from ponds and rivulets, lichens and moss/vegetation from homothermic springs were sampled. In all, 61 stations were sampled from 0 to $726 \mathrm{~m}$ asl.

A portion of the moss and freshwater samples was sorted immediately after sampling in the laboratory at the faculty of Science \& Technology, University of the Faroe islands, Tórshavn. The remaining material was either air dried or frozen for later sorting at the Zoological Museum, the Natural History Museum of Denmark, Copenhagen. Dried samples were first soaked in distilled refrigerated water and left for at least one hour in order to revive as many animals as possible. Samples were carefully torn into smaller pieces and rinsed vigorously through a $63 \mu \mathrm{m}$ mesh plankton net. The remaining sediment was decanted into a Petri dish for sorting under a Leica stereomicroscope. Frozen samples were first thawed out in distilled water at room temperature and afterwards treated the same way as dry samples.

The sorted specimens were prepared for light microscopy for observation, identification and microphotography. Polyvinyl lactophenol (PVL) was primarily used for the permanent mounts. Some specimens were mounted on microslides in a drop of water and covered with coverslips to observe and photograph live animals. These were subsequently infused with a graded series of glycerine (6.25, $12.5,25,50,75 \%$ ) for a more permanent mount. Specimens were observed and identified on a Leica light micro- scope using phase contrast and on an Olympus BX51 light microscope using differential interference contrast (DIC, Nomarski technique), and micrographs were taken with a Olympus C-3030 zoom digital camera.

The statistical program Primer, version 6.1.4 (Clarke and Gorley, 2006), was used for data analysis. Only presence/absence data were used. Bray-Curtis similarities were calculated to compare the tardigrade fauna between countries and a cluster analysis was performed based on group average linking. The species accumulation plot was calculated with the non-parametric species estimators, Chao 2, Jacknife 1 and 2, Bootstrap and Michaelis-Menten with 999 random rearrangements of the sample ordering.

Information on recorded tardigrade species from neighbouring islands and countries was retrieved from the literature as follows: Greenland (excluding Disko island) from Petersen (1951); Disko island, Greenland, from Grøngaard et al. (1990), Pape (1986) and Hansen and Katholm (2002); Iceland from Marley and Wright (1996); Britain from Morgan (1976); Newfoundland from Bateman and Collins (2001); Svalbard from Maucci (1996).

To test whether or not there is any altitudinal distribution pattern of the tardigrade species found on the Faroe islands, the occurrences of the specimens were divided into vegetational altitudinal zones, according to the vegetational zones found by Fosaa (2004). The lowest temperate zone was $0-200 \mathrm{~m}$ asl (zone 1), a middle low alpine zone from 200-400 $\mathrm{m}$ asl (zone 2), and an alpine zone above $400 \mathrm{~m}$ asl (zone 3). According to Christiansen and Mortensen (2002), the border between temperate and arctic climates on the Faroe islands was at $216 \mathrm{~m}$ asl. For comparison of the altitudinal distribution of the tardigrade species, we have used information on Polish tardigrades from Dastych $(1987,1988)$ that is among the most extensive studies done in this field. Dastych divided Poland into distinct areas in relation to altitude, the lowlands (0-200 $\mathrm{m}$ asl), the uplands (201-500 $\mathrm{m}$ asl), the foreland (501$1000 \mathrm{~m}$ asl) and the mountains (above $1000 \mathrm{~m}$ asl, highest point in Poland $2499 \mathrm{~m}$ asl, Rysy Mt.). The mountains were divided into three zones with $500 \mathrm{~m}$ intervals (Subalpine, Mesoalpine, Eualpine).

The collection of specimens in this study have been deposited in the Zoological Museum, the Natural History Museum of Denmark, University of Copenhagen, Denmark.

\section{RESULTS}

\section{Species richness}

In all 48 species including subspecies were found, of which 29 are new records (Tab. 1). The limnoterrestrial tardigrade fauna on the Faroe islands were represented by members from both classes of the Tardigrada: Heterotardigrada and Eutardigrada. There was one family of Heterotardigrada represented, i.e. Echiniscidae. In addition 


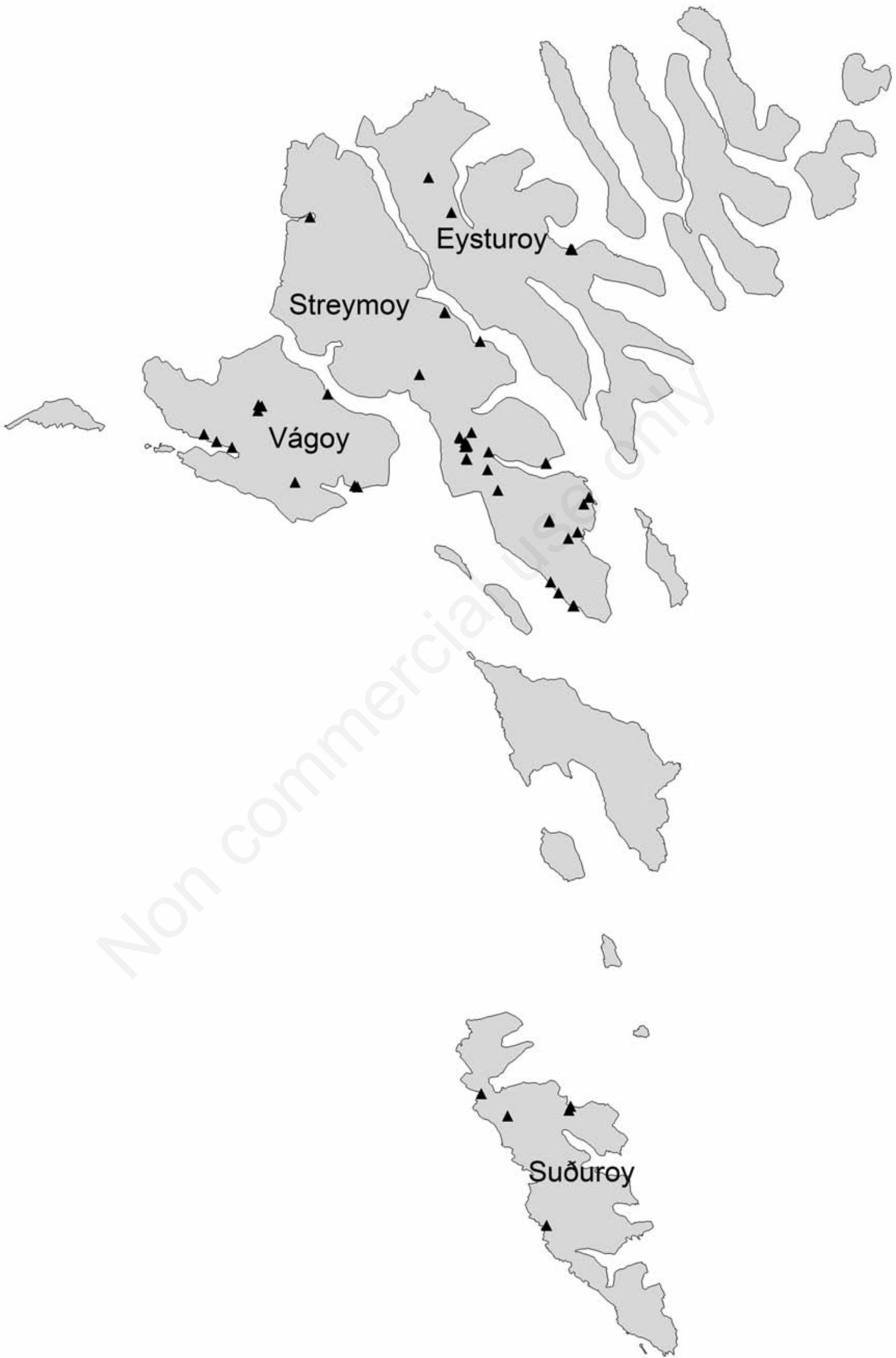

Fig. 1. Faroe islands. Overview of sampling stations (black triangles). 
a marine species belonging to Echiniscoididae has been found, namely Echiniscoides sigismundi (M. Schultze, 1865). Within the Eutardigrada there were 8 families represented, i.e. Milnesiidae, Eohypsibiidae, Calohypsibiidae, Hypsibiidae, Ramazzottiidae, Isohypsibiidae, Macrobiotidae and Murrayidae.

To test whether or not the sampling was sufficient for finding the highest number possible of species represented on the Faroes, a species accumulation plot was computed using Primer version 6.1.4. In Fig. 2 the different non- parametric estimators used, i.e. Chao 2, Jacknife 1 \& 2, Bootstrap and Michaelis-Menten (MM), have almost but not quite reached their asymptotes. The actual number of species and subspecies observed (Sobs) is 49 and the MM estimator curve lies beneath the Sobs curve and therefore underestimates the actual number of species found. The Jacknife 1 and 2 and Bootstrap estimators have a final estimate of 63, 70 and 55 species, respectively, and are gradually creeping upwards. The Chao 2 estimator has a final estimate of 63 species and the curve is almost flat; at 10

Tab. 1. List of species and subspecies for the Faroe islands.

\begin{tabular}{|c|c|c|c|c|c|}
\hline & Class & Order & Family & Subfamily & Species \\
\hline 1 & Heterotardigrada & Echiniscoidea & Echiniscidae & & Echiniscus arctomys Ehrenberg, 1853 \\
\hline 2 & & & & & Echiniscus blumi blumi Richters, $1903^{*}$ \\
\hline 3 & & & & & Echiniscus merokensis merokensis Richters, 1904 \\
\hline 4 & & & & & Echiniscus merokensis suecicus Thulin, 1911 \\
\hline 5 & & & & & Echiniscus quadrispinosus quadrispinosus Richters, 1902 \\
\hline 6 & & & & & Echiniscus testudo (Doyère, 1840) \\
\hline 7 & & & & & Echiniscus trisetosus Cuénot, 1932 \\
\hline 8 & & & & & Echiniscus wendti Richters, $1903^{*}$ \\
\hline 9 & & & & & Hypechiniscus exarmatus (Murray, 1907)* \\
\hline 10 & & & & & Hypechiniscus gladiator gladiator (Murray, 1905)* \\
\hline 11 & & & & & Pseudechiniscus facettalis Petersen, 1951 \\
\hline 12 & & & & & Pseudechiniscus islandicus (Richters, 1904)* \\
\hline 13 & & & & & Pseudechiniscus suillus (Ehrenberg, 1853)* \\
\hline 14 & Eutardigrada & Apochela & Milnesiidae & & Milnesium tardigradum (Doyère, 1840)* \\
\hline 15 & & Parachela & Eohypsibidae & & Austeruseus faeroensis Trygvadóttir and Kristensen, 2011* \\
\hline 16 & & & & & Austeruseus balduri Trygvadóttir and Kristensen, 2011* \\
\hline 17 & & & & & Austeruseus rokuri Trygvadóttir and Kristensen, 2011* \\
\hline 18 & & & & & Bertolanius weglarskae (Dastych, 1972) (F)* \\
\hline 19 & & & & & Eohypsibius nadjae Kristensen, $1982^{*}$ \\
\hline 20 & & & Calohypsibiidae & & Calohypsibius ornatus Richters, 1900 \\
\hline 21 & & & Hypsibiidae & Diphasconinae & Diphascon (Diphascon) bullatum Murray, 1905 \\
\hline 22 & & & & & Diphascon (Diphascon) pingue pingue (Marcus, 1936) \\
\hline 23 & & & & & Diphascon (Diphascon) recamieri Richters, 1911 \\
\hline 24 & & & & & Diphascon (Diphascon) tenue Thulin, $1928^{*}$ \\
\hline 25 & & & & & Diphascon (Adropion) scoticum scoticum Murray, $1905^{*}(\mathrm{~F})$ \\
\hline 26 & & & & & Diphascon (Adropion) scoticum ommatophorum (Thulin, 1911) \\
\hline 27 & & & & Hypsibiinae & Borealibius zetlandicus (Murray, 1907) \\
\hline 28 & & & & & Hypsibius convergens (Urbanowicz, 1925) (F) \\
\hline 29 & & & & & Hypsibius dujardini (Doyère, 1840) (F) \\
\hline 30 & & & & & Hypsibius pallidus Thulin, 1911 (F) \\
\hline 31 & & & & Itaquasconinae & Platicrista angustata (Murray, 1905) \\
\hline 32 & & & Ramazzottidae & & Ramazzottius oberhaeuseri (Doyère, 1840 ) ${ }^{*}$ \\
\hline 33 & & & Isohypsibiidae & & Isohypsibius monoicus (Bertolani, 1981) (F) \\
\hline 34 & & & & & Thulinius ruffoi (Bertolani, 1982) (F) \\
\hline 35 & & & Macrobiotidae & & Adorybiotus granulatus (Richters, 1903) \\
\hline 36 & & & & & Macrobiotus ariekammensis Weglarska, 1965 \\
\hline 37 & & & & & Macrobiotus coronatus de Barros, 1942 \\
\hline 38 & & & & & Macrobiotus echinogenitus Richters, 1904 \\
\hline 39 & & & & & Macrobiotus harmsworthi Murray, $1907^{*}$ \\
\hline 40 & & & & & Macrobiotus hufelandi Schultze, 1834* (F) \\
\hline 41 & & & & & Macrobiotus islandicus Richters, $1904^{*}$ \\
\hline 42 & & & & & Macrobiotus occidentalis striatus Dastych, 1974 \\
\hline 43 & & & & & Macrobiotus orcadensis Murray, 1907 \\
\hline 44 & & & & & Paramacrobiotus areolatus (Murray, 1907) \\
\hline 45 & & & & & Paramacrobiotus richtersi (Murray, 1911) (F) \\
\hline 46 & & & Murrayidae & & Dactylobiotus ambiguus (Murray, 1907)* (F) \\
\hline 47 & & & & & Dactylobiotus dispar (Murray, 1907) (F) \\
\hline 48 & & & & & Murrayon pullari (Murray, 1907) (F) \\
\hline
\end{tabular}

F, freshwater species (the remaining species are limnoterrestrial). "Previous records. 
samples it already estimates 50 species, which makes this the most realistic estimate.

\section{The Faroese fauna compared to neighbouring islands in the northeast Atlantic ocean}

To compare the Faroese tardigarde fauna with those of the neighbouring islands in the northeast Atlantic ocean we selected Iceland, Svalbard, Disko island, Greenland (excluding Disko island), Scotland, England, and Newfoundland. On the basis of presence/absence data of the tardigrade species from the differrent countries, a cluster analysis was computed based on the Bray-Curtis similarities, and a dendrogram based on group-average linking was constructed. The dendrogram (Fig. 3) showed the similarities between areas in $\%$. A value closer to $100 \%$ means a higher similarity. The dendrogram of Fig. 3 showed two groups. The group farthest to the left is Newfoundland. England/Scotland came out as one group and the other group consisted of Disko island, Faroe islands, Iceland, Greenland (excluding Disko island) and Svalbard. In this latter group Disko island and the Faroes were closest to Iceland, which was right next to the Faroes with a higher similarity. Greenland and Svalbard were grouped together with a higher similarity than with the rest in the group. Disko island and Faroe islands shared more species than Disko island and the rest of Greenland. Iceland was very similar to the Faroes but also to Greenland and Svalbard in species composition.

Tab. 2 shows how many species and subspecies the countries/islands shared and the total number of species and subspecies for each country/island. The Faroes shared most species and subspecies (30) with Iceland, and shared 23 species and subspecies with Disko island, 22 with Greenland, and 21 with Svalbard. England and Scotland shared 10 and 18 species, respectively, and Newfoundland shared 12 species.

In Fig. 4 is a non-metric Multi Dimensional Scaling (nMDS) plot of the similarities in tardigrade species composition between the countries, which complements the dendrogram in Fig. 3. The nMDS plot is an alternative method to visualize the Bray-Curtis similarities, which instead are calculated as distances between the countries in relation to each other. It also shows Newfoundland as farthest away from the Faroe islands because they are not very similar in species composition. Scotland and England are also placed farther away, but Scotland is closer as would be expected from a geographical point of view. Closest to the Faroes is Iceland and Disko island. Iceland also shows a close affinity to Greenland (excluding Disko) and Svalbard, which also corresponds to their geographical position.

\section{Altitudinal distribution}

The altitudinal distribution of tardigrade species from Faroe islands has been made according to Fosaa (2004; Tab. 3) and was compared to Dastych's findings (1987, 1988) on altitudinal patterns in Polish tardigrades.

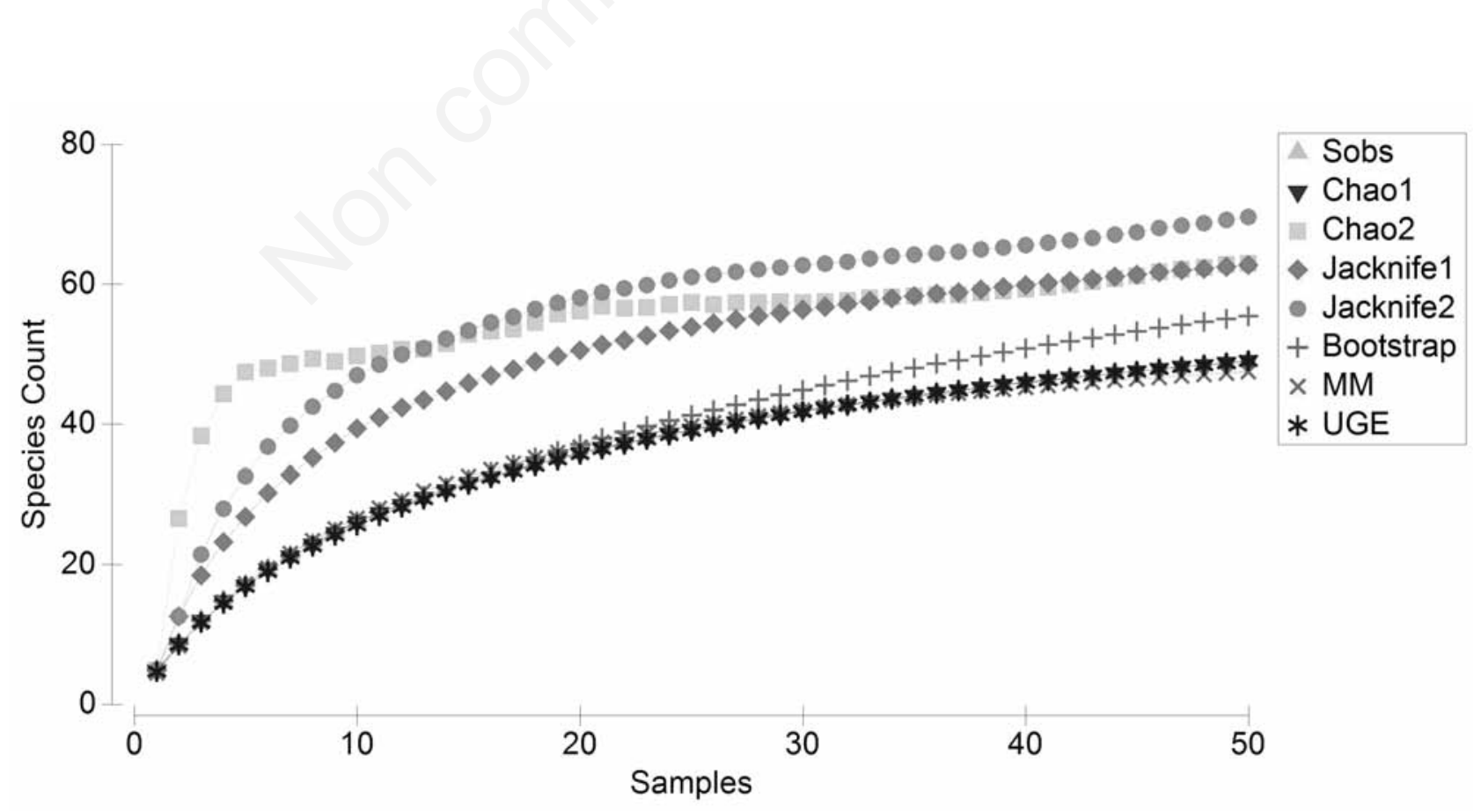

Fig. 2. Species accumulation curves for the Faroe islands. Observed number of species/subspecies (Sobs). Chao 2, Jacknife 1 \& 2 , Bootstrap and MM (Michaelis-Menten) are the different species richness estimators used. 
Lowland species (not exceeding $200 \mathrm{~m}$ asl) were, among others, Murrayon pullari (Murray, 1907). On the Faroes M. pullari was found in zone 1 and 3. One upland species (center of distribution was 201-500 m asl, but occurred more rarely in neighbouring zones) was Echiniscus testudo (Doyère, 1840). This species was found on the Faroes in zone 1. Foreland species (501-1000 m asl) Macrobiotus ariekammensis Weglarska, 1965 was found on the Faroes found in zone 2. Montaine species (center of distribution above $1000 \mathrm{~m}$ asl) found in Poland were, among others, Echiniscus wendti Richters, 1903, Echinis- cus merokensis Richters, 1904, Dactylobiotus ambiguus, B. weglarskae, Calohypsibius ornatus (Richters, 1900), Diphascon recamieri Richters, 1911 and Platicrista angustata (Murray, 1905). On the Faroes E. wendti and E. merokensis were found in all three zones. D. ambiguus, $B$. weglarskae and C. ornatus were found in zone 1 and 3. Diphascon recamieri was only found once, in zone 1, and $P$. angustata was also found once in the highest zone 3. The tychoalpine (euryzonal) species (those that occur in all altitudinal zones) in Poland, which also occurred on the Faroe islands are Echiniscus blumi Richters, 1903,

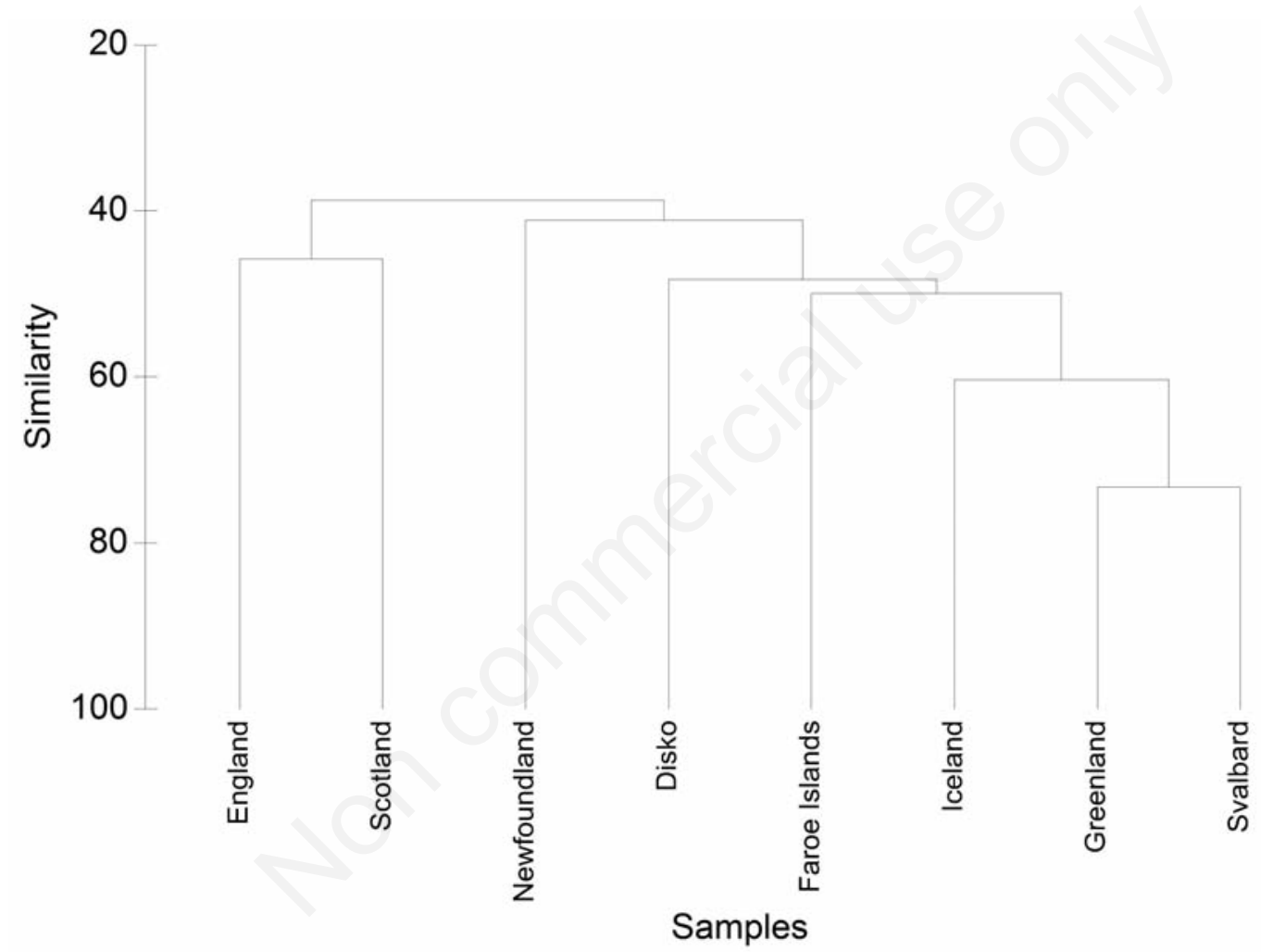

Fig. 3. Dendrogram showing similarities in the terrestrial tardigrade fauna from the selected countries/islands.

Tab. 2. Number of shared tardigrade species and subspecies and total number of tardigrade species/subspecies for each locality.

\begin{tabular}{|c|c|c|c|c|c|c|c|c|}
\hline & Greenland & Disko i. & Iceland & Svalbard & Faroe i. & England & Scotland & N. Foundland \\
\hline Greenland & - & 21 & 32 & 33 & 22 & 12 & 15 & 18 \\
\hline Disko i. & - & - & 29 & 21 & 23 & 9 & 15 & 14 \\
\hline Iceland & - & - & - & 30 & 30 & 14 & 20 & 18 \\
\hline Svalbard & - & - & - & - & 21 & 13 & 16 & 16 \\
\hline Faroe i. & - & - & - & - & - & 10 & 18 & 12 \\
\hline England & - & - & - & - & - & - & 11 & 7 \\
\hline Scotland & - & - & - & - & - & - & - & 11 \\
\hline N. Foundland & - & - & - & - & - & - & - & - \\
\hline Total number of species & 53 & 49 & 58 & 37 & 49 & 18 & 30 & 27 \\
\hline
\end{tabular}

Disko i., Disko island; Faroe i., Faroe island; N. Foundland, New Foundland. 
Pseudechiniscus suillus (Ehrenberg, 1853), Macrobiotus hufelandi C.A.S. Schultze, 1834, Macrobiotus echinogenitus Richters, 1904, Macrobiotus harmsworthi Murray, 1907, Paramacrobiotus richtersi (Murray, 1911), Hypsibius dujardini (Doyère, 1840), Hypsibius convergens (Urbanowicz, 1925), Hypsibius pallidus Thulin, 1911, Ramazzottius oberhaeuseri (Doyère, 1840), Diphascon bullatum (Iharos, 1964), Diphascon scoticum scoticum Murray, 1905, Dipahscon pingue (Marcus, 1936), Milnesium tardigradum Doyère, 1840 and Dactylobiotus dispar (Murray, 1907). In the Faroes, M. hufelandi, M. echinogenitus, M. harmsworthi and $M$. tardigradum, which have been considered cosmopolitan species, and P. richtersi, reported from Europe (McInnes, 1994), occurred in all three zones. They were also the most frequently found species on the Faroes. Pseudechiniscus suillus was found in zone $1, H$. dujardini and $H$. convergens in zones 1 and $3, H$. pallidus in zone $1, R$. oberhaeuseri in zone 1.D. bullatum and D. scoticum in zone 1 , and $D$. pingue in zones 1 and 3.

\section{DISCUSSION}

\section{Comments on some of the previous records}

Compared to the species previously reported from the Faroe islands, only the form spinosissimus of the species
C. ornatus was not found again in this study. However this variety is not valid as a subspecies according to Guidetti and Bertolani (2005). The two species M. dubius and D. macronyx are stated as species inquirendae (Ramazzotti and Maucci, 1983; Guidetti and Bertolani, 2005) and are therefore not considered as valid species. According to Ramazzotti and Maucci (1983), D. macronyx and $D$. dispar could be synonyms, and the smooth eggs reportedly laid in the exuvia of $D$. macronyx could instead belong to coexisting tardigrade species. However, as previously mentioned we can not state with certainty that Tuxen's species belongs to Dactylobiotus. Sellnick (1908) found some specimens belonging to the genus Echiniscus but did not assign them to species. He added a figure and described the specimens has having five lateral hairs (i.e. cirrus $\mathrm{A}, \mathrm{B}, \mathrm{C}, \mathrm{D}$, and $\mathrm{E}$ ), two spines dorsally on paired plate II, one on each side, although in one specimen there was only one spine present. The plates were granular, $4^{\text {th }}$ legs with a dentate collar, 4 claws on each leg and the two middle claws with a basal spur. On the basis of this description one is led to think that these specimens could be either E. merokensis suecicus or E. quadrispinosus cribrosus. Both E. merokensis suecicus and E. quadrispinosus, but not the subspecies cribrosus, have been found again on the Faroe islands in this study. It is likely to think that these also were present back in the early 1900s, but Sell-

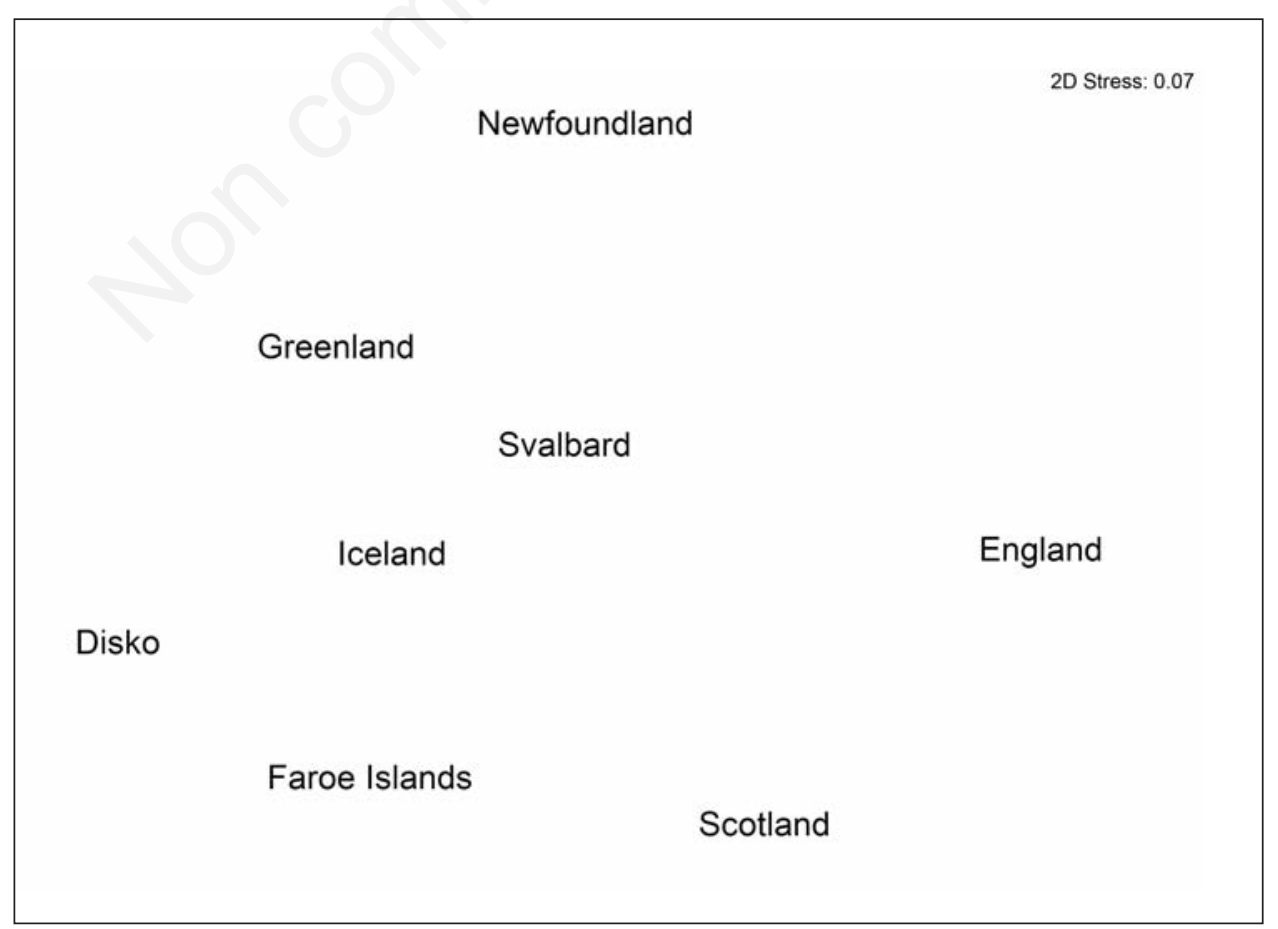

Fig. 4. Non-metric multi dimensional scaling plot of the similarities in tardigrade species/subspecies composition between selected countries/islands. Stress is 0.07 . 
nick either didn't have knowledge of the then newly described subspecies E. quadrispinosus cribrosus or just did not identify his specimens as belonging to this subspecies. It is also possible that Sellnick's specimens could belong to the later described subspecies E. merokensis suecicus, described by Thulin in 1911, which was found again in this study. Tuxen (1941) found one specimen, not identified at species level, which he ascribed to the genus Isohypsibius. He stated it resembled Isohypsibius prosostomus Thulin, 1928 but was a juvenile. It was not sufficiently described and therfore not possible to determine more clearly. Only two Isohypsibiids were found on the Faroe islands: i.e. Isohypsibius monoicus R. Bertolani, 1981 and Thulinius ruffoi (R. Bertolani, 1982).

\section{Zoogeographic and altitudinal distribution}

Geographically it was expected that the Icelandic and Faroese tardigrade faunas were similiar, but the fact that the tardigrade fauna on Disko island, which is much farther away on the west coast of Greenland, also resembled the Faroese fauna is far more surprising. This result could probably change when the localities are sampled further and new species are recorded and previously misidentified species are corrected. According to Pugh and McInnes (1998), the arctic tardigrade fauna is probably mostly derived from nearctic wind-blown propagules that colonised these northern areas in the Holocene period. The tardigrade fauna is probably very old and survived glaciation periods in refuges such as nunataks, which also have occurred on the Faroes during glaciation periods (Rasmussen 1984; Mortensen, 2002). The Faroes and Disko island are also similiar geologically in age and origin as part of the North Atlantic Igneous Province (Rasmussen, 1981).

Dastych (1988) noted, in his extensive work on altitudinal distributions of tardigrades of Poland, the northern-mountain disjunction, i.e. species that occur in the Arctic and to the north also occur in Poland in the mountains to the south. This distribution pattern is a relic from the cold periods of the Pleistocene (Dastych, 1988). Findings of E. nadjae first on Disko island, Greenland (Kristensen, 1982) and then on the Faroe islands and in the high mountains of Italy (Bertolani and Kristensen, 1987; McInnes, 1994) also fit the northern-mountain (boreoalpine) type of distributional pattern (Bertolani and Kristensen, 1987). B. weglarskae also has this type of distribution (Bertolani and Kristensen, 1987; McInnes, 1994 ) and the finding of I. monoicus, which previously only is known from Italy (Bertolani, 1981, 1982; McInnes, 1994), supports the idea of glacial relics. Borealibius zetlandicus and Pseudechinsicus islandicus (Richters, 1904) both present a boreo-alpine distribution pattern (McInnes, 1994; Pilato et al., 2006). At least a part of the Faroese tardigrade fauna could be very ancient, dat- ing as far back as the glaciation periods or even before.

The altitudinal distribution of the tardigrade species is noteworthy because the Polish montane species only occurring above $1000 \mathrm{~m}$ asl and the corresponding species on the Faroes were found either in all three zones or in the lowest and highest zone. Two exceptions from this were $P$. angustata, which only was found once in the highest zone, and $D$. recamieri, found once in the lowest zone.

Tab. 3. Altitudinal distribution of the tardigrade species and subspecies on the Faroe islands.

\begin{tabular}{|c|c|c|c|}
\hline $\begin{array}{l}\text { Tardigrade species } \\
\text { and sub-species }\end{array}$ & $\begin{array}{c}\text { Zone } 1 \\
0-200< \\
\mathrm{m} \text { asl }\end{array}$ & $\begin{array}{c}\text { Zone } 2 \\
<200-400< \\
\text { m asl }\end{array}$ & $\begin{array}{c}\text { Zone } 3 \\
>400 \\
\mathrm{~m} \text { asl }\end{array}$ \\
\hline Echiniscus arctomys & $\mathrm{x}$ & & \\
\hline Echiniscus blumi blumi & $\mathrm{x}$ & & \\
\hline Echiniscus merokensis merokensis & $\mathrm{x}$ & $\mathrm{x}$ & $\mathrm{x}$ \\
\hline Echiniscus merokensis suecicus & $\mathrm{x}$ & $\mathrm{x}$ & \\
\hline Echiniscus quadrispinosus quadrispinosus & $\mathrm{x}$ & & \\
\hline Echiniscus testudo & $\mathrm{x}$ & & \\
\hline Echiniscus trisetosus & $\mathrm{x}$ & & \\
\hline Echiniscus wendti & $\mathrm{x}$ & $\mathrm{x}$ & $\mathrm{x}$ \\
\hline Hypechiniscus exarmatus & $\mathrm{x}$ & & \\
\hline Hypechiniscus gladiator gladiator & $\mathrm{x}$ & & $\mathrm{x}$ \\
\hline Pseudechiniscus facettalis & $\mathrm{x}$ & & \\
\hline Pseudechiniscus islandicus & $\mathrm{x}$ & $\mathrm{x}$ & $\mathrm{x}$ \\
\hline Pseudechiniscus suillus & $\mathrm{x}$ & & \\
\hline Milnesium tardigradum & $\mathrm{x}$ & $\mathrm{x}$ & $\mathrm{x}$ \\
\hline Austeruseus faeroensis & $\mathrm{x}$ & & $\mathrm{x}$ \\
\hline Austeruseus balduri & $\mathrm{x}$ & & $\mathrm{x}$ \\
\hline Austeruseus rokuri & $\mathrm{x}$ & & $\mathrm{x}$ \\
\hline Bertolanius weglarskae & $\mathrm{x}$ & & $\mathrm{x}$ \\
\hline Eohypsibius nadjae & $\mathrm{x}$ & & \\
\hline Calohypsibius ornatus & $\mathrm{x}$ & & $\mathrm{x}$ \\
\hline Diphascon (D.) bullatum & $\mathrm{x}$ & & \\
\hline Diphascon (D.) pingue pingue & $\mathrm{x}$ & & $\mathrm{X}$ \\
\hline Diphascon (D.) recamieri & $\mathrm{x}$ & & \\
\hline Diphascon (D.) tenue & $\mathrm{x}$ & $\mathrm{x}$ & $\mathrm{x}$ \\
\hline Diphascon (A.) scoticum scoticum & $\mathrm{x}$ & & \\
\hline Diphascon (A.) scoticum ommatophorum & & & $\mathrm{x}$ \\
\hline Borealibius zetlandicus & $\mathrm{x}$ & $\mathrm{x}$ & $\mathrm{x}$ \\
\hline Hypsibius convergens & $\mathrm{x}$ & & $\mathrm{x}$ \\
\hline Hypsibius dujardini & $\mathrm{x}$ & & $\mathrm{x}$ \\
\hline Hypsibius pallidus & $\mathrm{x}$ & & \\
\hline Platicrista angustata & & & $\mathrm{x}$ \\
\hline Ramazzottius oberhaeuseri & $\mathrm{x}$ & & \\
\hline Isohypsibius monoicus & $\mathrm{x}$ & & \\
\hline Thulinius ruffoi & $\mathrm{x}$ & & $\mathrm{x}$ \\
\hline Adorybiotus granulatus & $\mathrm{x}$ & & \\
\hline Macrobiotus ariekammensis & & $\mathrm{x}$ & \\
\hline Macrobiotus coronatus & $\mathrm{x}$ & $\mathrm{x}$ & $\mathrm{x}$ \\
\hline Macrobiotus echinogenitus & $\mathrm{x}$ & $\mathrm{x}$ & $\mathrm{x}$ \\
\hline Macrobiotus harmsworthi & $\mathrm{x}$ & $\mathrm{x}$ & $\mathrm{x}$ \\
\hline Macrobiotus hufelandi & $\mathrm{x}$ & $\mathrm{x}$ & $\mathrm{x}$ \\
\hline Macrobiotus islandicus & $\mathrm{x}$ & & $\mathrm{x}$ \\
\hline Macrobiotus occidentalis striatus & $\mathrm{x}$ & & \\
\hline Macrobiotus orcadensis & & & $\mathrm{x}$ \\
\hline Paramacrobiotus areolatus & $\mathrm{x}$ & & $\mathrm{x}$ \\
\hline Paramacrobiotus richtersi & $\mathrm{x}$ & $\mathrm{x}$ & $\mathrm{x}$ \\
\hline Dactylobiotus ambiguus & $\mathrm{x}$ & & $\mathrm{x}$ \\
\hline Dactylobiotus dispar & $\mathrm{x}$ & & \\
\hline Murrayon pullari & $\mathrm{x}$ & & $\mathrm{x}$ \\
\hline
\end{tabular}


In Poland, M. pullari was a lowland species but it occurred in the lowest and highest zone on the Faroes. The Polish tychoalpine (euryzonal) species corresponded well with the Faroese findings. Since the frequency of findings in the different zones was not very high (due to the scattered and qualitatively mode of sampling), some only based on one individual, the results are only presented as a guide of what might be expected. In contrast, the altitude per se may not be a reliable predictor of species composition, as reported in several studies. In addition, many species identifications in the past have been incorrect and the idea of cosmopolitan tardigrades is rapidly changing. One conclusion that can be made, however, is that the northern latitude of the Faroes plays a role and that the species typically found in high altitudes farther south may also be present at lower altitudes farther north.

\section{CONCLUSIONS}

In summary, this study has reported a total of 48 tardigrade species including subspecies and one marine species on the Faroes, of which 29 are new to the Faroese fauna. Three of the species found during the investigation belong to the newly described genus Austeruseus Trygvadóttir and Kristensen, 2011 within the family Eohypsibiidae (Bertolani and Kristensen, 1987). With members from all genera in the Eohypsibiidae represented, the tardigrade fauna on the Faroe islands is the richest in the world in this family. The species composition of the tardigrade fauna of the Faroe islands resembles that of the nearest neighbouring islands and countries and is most similar to Iceland with 30 species including subspecies in common. Secondly and more surprising, the fauna is also very similar to the fauna of Disko island, West Greenland, which could indicate survival of tardigrade species in refuges such as nunataks. However Disko island has been thoroughly studied over many years, and the similarity may be related to sampling effort. For some species there may be a boreo-alpine type of distributional pattern. Future research on the tardigrade fauna on the Faroe islands would probably add new species to the list as more habitats and the smaller islands in the archipelago are sampled.

\section{ACKNOWLEDGMENTS}

The authors would like to thank the University of the Faroe islands, Science \& Technology Department. We would also like to thank Prof. Roberto Bertolani (University of Modena, Italy) for identifying the specimens of Isohypsibius monoicus.

\section{REFERENCES}

Bateman L, Collins M, 2001. A preliminary account of the tardigrades of Newfoundland. Zool. Anz. 240: 223-232.

Bertolani R, 1981. A new genus and five new species of Italian fresh-water tardigrades. Boll. Mus. Civ. St. Nat. Verona 8:249-254.

Bertolani R, 1982. Tardigradi (Tardigrada). [Guide per il riconoscimento delle specie animali delle acque interne Italiane]. [Article in Italian]. Quaderni del Consiglio Nazionale delle Richerche AQ/1/168, 15:1-104.

Bertolani R, Kristensen RM, 1987. New records of Eohypsibius nadjae Kristensen, 1982, and revision of the taxonomic position of two genera of Eutardigrada (Tardigrada), p. 359372. In: R. Bertolani (ed.), Biology of Tardigrades. Selected Symposia and Monographs U.Z.I., 1. Mucchi ed.

Bertolani R, Rebecchi L, Claxton SK, 1996. Phylogenetic significance of egg shell variation in tardigrades. Zool. J. Linn. Soc. 116:139-148.

Christiansen HH, Mortensen L.E, 2002. Arctic mountain meteorology at the Sornfelli mountain in year 2000 in the Faroe Islands. Ann. Soc. Sci. Færoensis 50:93-110.

Clarke KR, Gorley RN, 2006. PRIMER v6: User Manual/Tutorial. PRIMER-E. Plymouth.

Dastych H, 1987. Altitudinal distribution of Tardigrada in Poland. In Biology of Tardigrades, p. 169-176. In: R. Bertolani (ed.), Biology of Tardigrades. Selected Symposia and Monographs U.Z.I., 1. Mucchi ed.

Dastych H, 1988. The Tardigrada of Poland. Monogr. Fauny Polski 16:1-255.

Fosaa AM, 2004. Altitudinal distribution of plant communities in the Faroe Islands. Ann. Soc. Sci. Færoensis 51:217-236.

Grøngaard A, Kristensen NM, Petersen MK, 1990. [Tardigradfaunaen på Disko]. [Article in Danish]. Feltkursus i Arktisk biologi, Godhavn, Københavns Universitet. ISBN 87981980-1-7, pp. 155-179.

Guidetti R, Bertolani R, 2005. Tardigrade taxonomy: an updated check list of the taxa and a list of characters for their identification. Zootaxa 845:1-46.

Hansen JG, Katholm AK, 2002. A study of the genus Amphibo$l u$ s from Disko Island with special attention on the life cycle Amphibolus nebulosus (Eutardigrada: Eohypsibiidae). Arctic Biology Field Course, Qeqertarsuaq, 2002. Zoological Museum, University of Copenhagen.

Kinchin I, 1994. The Biology of Tardigrades. Portland Press Ltd, London: $186 \mathrm{pp}$.

Kristensen RM, 1982. New aberrant eutardigrades from homothermic springs on Disko Island, West Greenland, p. 203220. In: D.R. Nelson (ed.), Proc. Third Int. Symp. Tardigrda. East Tennessee State Univ. Press, Johnson City, Tennessee.

Manicardi GC, Bertolani R, 1987. First contribution to the knowledge of alpine grassland tardigrades, p. 177-185. In: R. Bertolani (ed.), Biology of Tardigrades. Selected Symposia and Monographs U.Z.I., 1, Mucchi ed.

Marley NJ, Wright DE, 1996. Amphibolus weglarskae (Dastych), a new addition to the Tardigrada of Iceland with an updated checklist of Icelandic species (Eohypsibiidae, Eutardigrada). Quekett J. Microscop. 37:541-545.

Maucci W, 1996. Tardigrada of the Arctic tundra with descriptions of two new species. Zool. J. Linn. Soc. 116:185-204.

McInnes S, 1994. Zoogeographic distribution of terrestrial/freshwater tardigrades from current literature. J. Nat. Hist. 28:257-352. 
Morgan CI, 1976. Studies on the British tardigrade fauna, some zoogeographical and ecological notes. J. Nat. Hist. 10:607632.

Mortensen LE, 2002. The geology and physical geography of some lakes in the Faroe Islands. Ann. Soc. Sci. Færoensis (Suppl. 36):14-27.

Pape T, 1986. Tardigrades, mites and insects from a bumblebee nest in Greenland. Ent. Medd. København 53:75-81.

Petersen B, 1951. The tardigrade fauna of Greenland. Medd. Grønland København 150:1-94.

Pilato G, Guidetti R, Rebecchi L, Lisi O, Hansen JG, Bertolani $\mathrm{R}, 2006$. Geonemy, ecology, reproductive biology and morphology of the tardigrade Hypsibius zetlandicus (Eutardigrada: Hypsibiidae) with erection of Borealibius gen. n. Polar Biol. 29:595-603.

Pugh PJA, McInnes S, 1998. The origin of Arctic terrestrial and freshwater tardigrades. Polar Biol. 19:177-182.

Ramazzotti G, Maucci W, 1983. The Phylum Tardigrada, $3^{\text {rd }}$ ed.
English translation by Clark W. Beasley. Originally published as Mem. Ist. Ital. Idrobiol. 41:1-1012.

Rasmussen J, 1981. [Øldir og Upphav]. [Article in Danish]. Emil Thomsen, Oddi hf., Tórshavn, pp. 1-211.

Rasmussen J, 1984. The Faroe Islands: geology. Grót og Grund. Føroya Fróðskaparfelag, Tórshavn, pp. 115-137.

Sellnick M, 1908. [Beitrag zur Moosfauna der Faröer]. [Article in German]. Zool. Anz. 33:208-12.

Thulin G, 1911. [Beitrag zur Kenntnis der Tardigradenfauna Schwedens]. [Article in German]. Ark. Zool. 7:1-60.

Thulin G, 1928. [Über Die Phylogenie Und Das System Der Tardigraden]. [Article in German]. Hereditas 11:207-266.

Trygvadóttir BV, Kristensen RM, 2011. Eohypsibiidae (Eutardigrada, Tardigrada) from the Faroe Islands with the description of a new genus containing three new species. Zootaxa 2886:39-62.

Tuxen SL, 1941. Tardigrada, p. 1-9. In: R. Spärck and S.L. Tuxen (eds.), The zoology of the Faroes. Andr. Fred. Høst \& Søn. 